\title{
Phylogenetic and phenotypic evidence for the transfer of Eubacterium aerofaciens to the genus Collinsella as Collinsella aerofaciens gen. nov., comb. nov.
}

\author{
Akiko Kageyama, Yoshimi Benno and Takashi Nakase
}

Japan Collection of Microorganisms, The Institute of Physical and Chemical Research (RIKEN), Wako, Saitama, 3510198, Japan

\author{
Author for correspondence: Akiko Kageyama. Tel: +81484671111 ext. 5141. Fax: +81484624619. \\ e-mail: kageyama@ulmus.riken.go.jp
}

\begin{abstract}
Three strains of Eubacterium aerofaciens, JCM 10188', JCM 7790 and JCM 7791, and 178 freshly isolated strains of the Eubacterium aerofaciens group from human faeces were characterized by biochemical tests, cell wall peptidoglycan type and 165 rRNA analysis. The Eubacterium aerofaciens group was divided into four groups by fermentation patterns of sucrose and cellobiose, and were further divided into 16 sub-groups by fermentation patterns of aesculin, salicin and amygdalin. All of the strains of the Eubacterium aerofaciens group were shown to be phylogenetically distantly related to Eubacterium limosum, which is the type species of genus Eubacterium. Eubacterium aerofaciens was shown to have a specific phylogenetic association with Coriobacterium glomerans. All the strains belonging to Eubacterium aerofaciens resembled Coriobacterium glomerans in possessing a high $\mathbf{G}+\mathrm{C}$ content $(60 \mathrm{~mol} \%)$. Cell wall analysis, however, revealed the presence of different A4 $\beta$ (L-Ala)-D-Glu-L-Orn-L-Asp peptidoglycan types. Based on a 165 rRNA sequence divergence of greater than $9 \%$ with Coriobacterium glomerans and the presence of a unique peptidoglycan type, a new genus, Collinsella, is proposed for Eubacterium aerofaciens, with one species, Collinsella aerofaciens. The type strain of Collinsella aerofaciens is JCM 10188'.
\end{abstract}

Keywords: Collinsella aerofaciens gen. nov., comb. nov., Eubacterium aerofaciens, $16 \mathrm{~S}$ rDNA, cell wall

\section{INTRODUCTION}

Intestinal microflora in humans and animals consists of many micro-organisms, both anaerobic and aerobic. Species of the genus Eubacterium, anaerobic Grampositive non-sporing rods, belong to the predominant micro-organisms of the intestinal microflora. The number and incidence of Eubacterium aerofaciens, in particular, are the highest in human intestine compared with other species of genus Eubacterium.

The genus Eubacterium contains uniform or pleomorphic non-sporing Gram-positive bacilli which are obligately anaerobic, they produce organic acids from carbohydrates or peptone, often including large amounts of butyric, acetic or formic acids. These

The GenBank/EMBLDDBJ accession numbers for the sequences determined in this paper are AB011814 (Eubacterium aerofaciens JCM 7790), AB011815 (JCM 7791) and AB011816 (JCM 10188'). micro-organisms do not produce propionic, lactic or succinic acids as a major acid product. This definition, by differentiation from other anaerobic genera on the basis of negative fermentation characteristics, provided a convenient, pragmatic classification when little or no phylogenetic data were available (Moore \& Holdeman-Moore, 1986). Because of its broad definition, this genus has over the years acted as a repository for a large number of phenotypically diverse species (Andreesen, 1992). In addition to this marked phenotypic heterogeneity, it is recognized that eubacteria are not phylogenetically homologous, with species dispersed among many of the different groups. In particular, the wide range of genomic DNA G $+C$ contents indicates that the genus includes organisms that are not related phylogenetically.

In this paper we report on the phenotypic and phylogenetic characterization of 181 strains of the Eubacterium aerofaciens group isolated from human 
Table 1. List of Eubacterium aerofaciens-like strains isolated from human faeces and their sources

\begin{tabular}{|c|c|c|c|c|}
\hline Group & $n$ & Strain name & Source* & Year \\
\hline \multirow[t]{7}{*}{ I-A } & 16 & JCM 7791 & American & \\
\hline & & RCA55-47, RCA55-95 & Healthy adults & 1986 \\
\hline & & RCA57-8, RCA57-76 & Healthy adults & 1986 \\
\hline & & RCA58-61 & Healthy adult & 1987 \\
\hline & & A2-231 & Canadian & 1982 \\
\hline & & A7-5, A7-10, A7-30, A7-48 & Healthy adults & 1978 \\
\hline & & A11-212, A11-250, A11-263, A11-264, A11-267 & CC patients & 1981 \\
\hline \multirow[t]{7}{*}{$\mathrm{I}-\mathrm{B}$} & 15 & RCA56-50 & Healthy adult & 1986 \\
\hline & & RCA57-62 & Healthy adult & 1986 \\
\hline & & RCA58-8 & Healthy adult & 1987 \\
\hline & & A2-156 & UC patient & 1978 \\
\hline & & A5-13 & Japanese & 1983 \\
\hline & & A7-15, A7-32, A7-58 & Healthy adults & 1978 \\
\hline & & A11-185, A11-194, A11-196, A11-197, A11-200, A11-254, A11-261 & CC patients & 1981 \\
\hline $\mathrm{I}-\mathrm{C}$ & 1 & A11-239 & CC patient & 1976 \\
\hline I-D & 2 & RCA55-19, RCA55-68 & Japanase & 1983 \\
\hline \multirow[t]{6}{*}{ I-E } & 19 & RCA56-51, RCA56-52, RCA56-56, RCA56-61 & Healthy adults & 1986 \\
\hline & & RCA57-7, RCA57-21 & Healthy adults & 1986 \\
\hline & & $\mathrm{A} 2-70, \mathrm{~A} 2-71$ & Japanese & 1981 \\
\hline & & A7-4, A7-53, A7-54 & Healthy adults & 1978 \\
\hline & & A9-8 & Japanese & 1981 \\
\hline & & A11-195, A11-208, A11-210, A11-231, A11-237, A11-251, A11-262 & $\mathrm{CD}$ patients & 1983 \\
\hline \multirow[t]{7}{*}{$\mathrm{I}-\mathrm{F}$} & 12 & RCA55-86 & Healthy adult & 1986 \\
\hline & & RCA56-76, RCA56-83 & Healthy adults & 1986 \\
\hline & & RCA57-63 & Healthy adult & 1986 \\
\hline & & $\mathrm{A} 1-75, \mathrm{~A} 1-78$ & Japanese & 1983 \\
\hline & & A2-44, A2-147 & UC patients & 1978 \\
\hline & & A7-3, A7-57 & Healthy adults & 1978 \\
\hline & & A11-191, A11-233 & UC patients & 1976 \\
\hline \multirow[t]{9}{*}{ II-A } & 44 & RCA2-45, RCA2-49 & Japanese & 1981 \\
\hline & & $\begin{array}{l}\text { RCA55-16, RCA55-18, RCA55-21, RCA55-24, RCA55-25, RCA55-30, RCA55- } \\
\text { 44, RCA55-51, RCA55-53, RCA55-57, RCA55-61, RCA55-93, RCA55-97 }\end{array}$ & Healthy adults & 1986 \\
\hline & & $\begin{array}{l}\text { RCA57-59, RCA57-60, RCA57-66, RCA57-67, RCA57-68, RCA57-70, RCA57- } \\
71, \text { RCA57-72, RCA57-81, RCA57-83, RCA57-89 }\end{array}$ & Healthy adults & 1986 \\
\hline & & RCA58-7, RCA58-11, RCA58-14, RCA58-15 & Healthy adults & 1987 \\
\hline & & A1-25 & Japanese & 1983 \\
\hline & & A2-227 & Canadian & 1982 \\
\hline & & $\mathrm{A} 3-65, \mathrm{~A} 3-89, \mathrm{~A} 3-122, \mathrm{~A} 3-215, \mathrm{~A} 3-231, \mathrm{~A} 3-232, \mathrm{~A} 3-264$ & Healthy adults & 1981 \\
\hline & & $\mathrm{A} 7-20, \mathrm{~A} 7-34, \mathrm{~A} 7-35, \mathrm{~A} 7-51$ & Healthy adults & 1978 \\
\hline & & A11-269 & CD patient & 1983 \\
\hline \multirow[t]{3}{*}{ II-B } & 19 & RCA55-23, RCA55-59, RCA74 & Healthy adults & 1986 \\
\hline & & RCA58-60 & Healthy adult & 1987 \\
\hline & & $\begin{array}{l}\text { A3-84, A3-85, A3-88, A3-90, A3-96, A3-124, A3-174, A3-175, A3-218, A3-227, } \\
\text { A3-229, A3-230, A3-238, A3-239, A3-242 }\end{array}$ & Japanese & 1981 \\
\hline \multirow[t]{3}{*}{ II-C } & 5 & A $1-51$ & Japanese & 1983 \\
\hline & & A3-51 & CC patient & 1976 \\
\hline & & A $7-2$, A $7-43$, A $7-56$ & Healthy adults & 1978 \\
\hline \multirow[t]{4}{*}{ II-D } & 14 & RCA2-35 & Japanese & 1981 \\
\hline & & $\begin{array}{l}\text { RCA55-3, RCA55-6, RCA55-20, RCA55-29, RCA55-36, RCA55-45, RCA55-46, } \\
\text { RCA55-52, RCA55-80, RCA55-87, RCA55-94 }\end{array}$ & Healthy aduits & 1986 \\
\hline & & RCA58-59 & Healthy adult & 1987 \\
\hline & & A1-102 & Japanese & 1983 \\
\hline II-E & 4 & RCA55-2, RCA55-22, RCA55-67, RCA55-88 & Healthy adults & 1986 \\
\hline
\end{tabular}


Table 1. (cont.)

\begin{tabular}{|c|c|c|c|c|}
\hline Group & $n$ & Strain name & Source* & Year \\
\hline \multirow[t]{5}{*}{ II-F } & 13 & RCA57-78 & Healthy adult & 1986 \\
\hline & & A1-45 & Japanese & 1983 \\
\hline & & A3-53, A3-72 & $\mathrm{CC}$ patients & 1976 \\
\hline & & A7-1, A7-16, A7-40, A7-41, A7-44, A7-50, A7-52, A7-55 & Healthy adults & 1978 \\
\hline & & A11-186 & Stomach cancer & 1981 \\
\hline II-G & 2 & A11-226, A11-228 & UC patients & 1976 \\
\hline \multirow[t]{4}{*}{ III-A } & 8 & JCM 10188T, JCM 7790 & American & \\
\hline & & RCA1-29 & Healthy adult & 1982 \\
\hline & & RCA57-32 & Healthy adult & 1986 \\
\hline & & A7-8, A7-11, A7-28, A7-31 & Healthy adults & 1978 \\
\hline \multirow[t]{4}{*}{ IV-A } & 6 & RCA1-28, RCA1-30 & Healthy adults & 1981 \\
\hline & & RCA55-85 & Healthy adult & 1986 \\
\hline & & RCA57-11 & Healthy adult & 1986 \\
\hline & & A7-6, A7-12 & Healthy adults & 1978 \\
\hline IV-B & 1 & A11-209 & UC patient & 1976 \\
\hline
\end{tabular}

* CC, Colon cancer; $\mathrm{CD}$, Crohn's disease; UC, ulcerative colitis.

faeces, including three deposited strains, JCM $10188^{\mathrm{T}}$, JCM 7790 and JCM 7791. On the basis of the results presented, we propose that these organisms be classified as Collinsella aerofaciens gen. nov., comb. nov.

\section{METHODS}

Bacterial strains studied and cultivation. The bacterial strains used in this study were 178 strains isolated from human faeces from 1977 to 1987 and three strains of Eubacterium aerofaciens JCM $10188^{\mathrm{T}}$ (= ATCC $25986^{\mathrm{T}}$ ), JCM 7790 and JCM 7791, as shown in Table 1. All strains were cultivated for $2 \mathrm{~d}$ at $37^{\circ} \mathrm{C}$ on EG agar [pre-mixed EG agar (Eiken Chemical) supplied with $5 \%$ horse blood that contains $3 \mathrm{~g}$ beef extract, $5 \mathrm{~g}$ yeast extract, $10 \mathrm{~g}$ peptone, $1.5 \mathrm{~g}$ glucose, $0.5 \mathrm{~g}$ L-cysteine. $\mathrm{HCl}, 0.2 \mathrm{~g} \mathrm{~L}$-cystine, $4 \mathrm{~g} \mathrm{Na} \mathrm{HPO}_{4}, 0.5 \mathrm{~g}$ soluble starch, $0.5 \mathrm{~g}$ Tween $80,0.5 \mathrm{~g}$ silicone and $15 \mathrm{~g}$ agar in $1000 \mathrm{ml}, \mathrm{pH} \mathrm{7}$.7] in an anaerobic chamber.

Phenotypic characteristics. Acid production from carbohydrates, assimilation of organic acids, nitrate reduction and hydrolysis of starch and gelatin were tested as described previously (Holdeman et al., 1977; Kaneuchi et al., 1976).

Chemotaxonomy. Freeze-dried cells for chemotaxonomic analyses were obtained from cultures grown in EGF broth [containing $2.4 \mathrm{~g} \mathrm{Lab}$-Lemco powder (Oxoid), $10 \mathrm{~g}$ Proteose peptone No. 3 (Difco), $5 \mathrm{~g}$ yeast extract (Difco), $4 \mathrm{~g}$ $\mathrm{Na}_{2} \mathrm{HPO}_{4}, 40 \mathrm{ml}$ sterilized horse blood, $5 \mathrm{~g}$ glucose, $0.5 \mathrm{~g}$ soluble starch (Sigma) and $0.5 \mathrm{~g} \mathrm{~L}$-cysteine. $\mathrm{HCl}$ in $960 \mathrm{ml}$ distilled water; pH 7.6] in an anaerobic chamber at $37^{\circ} \mathrm{C}$.

Cell wall peptidoglycan was prepared and hydrolysed by the methods of Kawamoto et al. (1981), and the amino acid composition was analysed with an automatic amino acid analyser (model 835; Hitachi). The neutral amino acid fraction was reacted with a chiral reagent $[(+)-1-(9-$ fluorenyl)ethyl chloroformate] and used for HPLC as described by Einarsson \& Josefsson (1987).

DNA studies. DNA was isolated as described by Saito \& Miura (1983). DNA base composition was estimated by HPLC (Fujimura, 1986; Tamaoka \& Komagata, 1984).
Levels of DNA-DNA relatedness were determined by the method of Ezaki et al. (1989) by using photobiotin and microplates.

165 rDNA sequencing. The $16 \mathrm{~S}$ rRNA gene was amplified using the PCR method and prokaryotic $16 \mathrm{~S}$ rDNA universal primers 27F (5' AGAGTTTGATCCTGGCTCAG $\left.3^{\prime}\right)$ and 1492R (5' GGTTACCTTGTTACGACTT 3'). PCR was performed with a DNA thermal cycler (Perkin-Elmer Cetus) using 30 cycles consisting of denaturation at $94{ }^{\circ} \mathrm{C}$ for $60 \mathrm{~s}$, primer annealing at $55^{\circ} \mathrm{C}$ for $150 \mathrm{~s}$, and primer extension at $72{ }^{\circ} \mathrm{C}$ for $150 \mathrm{~s}$ (with $30 \mathrm{~s}$ per cycle added). Ligation was performed using plasmid pT7 Blue T-Vector (Novagen) and a ligation kit (Takara Shuzo) as recommended by the manufacturers. Transformation provided Escherichia coli MJ1190 competent cells and select colonies for analysis. Plasmids were prepared for sequencing using the alkaline lysis method.

Sequencing was performed using the ALFred AutoCycle Sequencing kit with an ALFexpress DNA sequencer (both from Pharmacia Biotech). These sequences were aligned with previously published sequences obtain from GenBank, including all species of the genus Eubacterium and related micro-organisms. Nucleotide substitution rates ( $K_{\text {nuc }}$ values) were calculated (Kimura \& Ohta, 1972), and phylogenetic trees were constructed by the neighbour-joining method (Saitou \& Nei, 1987). The topology of the trees was evaluated by performing a bootstrap analysis of the sequence data with the CLUSTAL w software (Thompson et al., 1994) (Fig. 2). The DNAML program in the PHYLIP 3.5c package (Felsenstein, 1985) was used for the maximum-likelihood analysis, with the default transition/transversion ratio of $2 \cdot 000000$ (Fig. 3).

\section{RESULTS}

\section{Morphological characteristics}

All of the strains which we studied were Gram-positive, non-sporing, anaerobic rods. Colonies were white in the centre with clear surroundings and protuberant on EG agar. Cells were $0.3-0.7 \times 1.2-4.3 \mu \mathrm{m}$ long and occurred in chains of 6-120 coccid cells. 
Table 2. Physiological and biochemical characteristics of strains of Eubacterium aerofaciens

Data are based on the reaction of our 178 isolated strains and Eubacterium aerofaciens JCM 10188 ${ }^{\mathrm{T}}$, JCM 7790 and JCM 7791. + , Positive; - , negative; $\mathrm{d}+,>80 \%$ positive; $\mathrm{d}-$, $>80 \%$ negative; $w+,>60-70 \%$ positive; $w-,>60-70 \%$ negative. All isolates produced acid from glucose, mannose, galactose, fructose, maltose and lactose. None produced acid from arabinose, xylose, melezitose, soluble starch, glycogen, mannitol, sorbitol, inositol or erythritol.

\begin{tabular}{|lcc|}
\hline Acid from: & Type strain & Other strains \\
\hline Arabinose & - & - \\
Xylose & - & - \\
Rhamnose & - & $\mathrm{d}-$ \\
Ribose & - & $\mathrm{d}-$ \\
Sucrose & + & $\mathrm{w}+$ \\
Maltose & + & + \\
Cellobiose & - & $\mathrm{d}+$ \\
Trehalose & - & $\mathrm{d}-$ \\
Raffinose & - & $\mathrm{d}-$ \\
Aesculin & - & $\mathrm{w}-$ \\
Salicin & - & $\mathrm{w}-$ \\
Amygdalin & - & $\mathrm{d}-$ \\
\hline
\end{tabular}

\section{Biochemical and physiological tests}

A total of 181 strains of the Eubacterium aerofaciens group isolated from human faeces and three strains of Eubacterium aerofaciens, JCM 10188 ${ }^{\mathrm{T}}$, JCM 7790 and JCM 7791, were characterized. All isolates produced acid from glucose, mannose, galactose, fructose, maltose and lactose. No isolates produced acid from arabinose, xylose, melezitose, soluble starch, glycogen, mannitol, sorbitol, inositol or erythritol (Table 2). Moore \& Holdeman (1974) recognized three phenotypic groups (I-III) of Eubacterium aerofaciens isolated

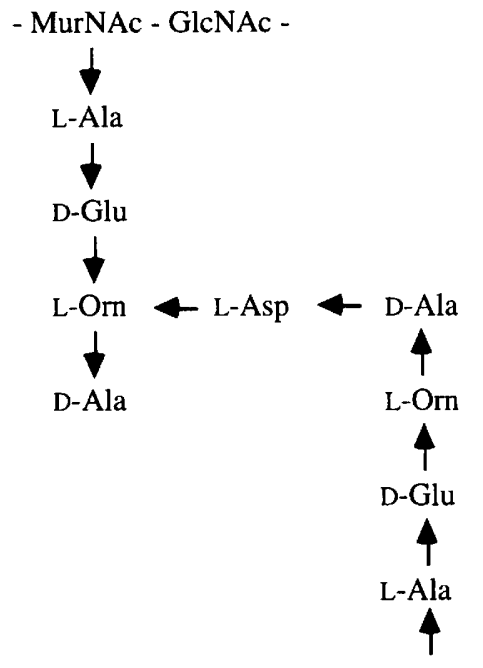

- GlcNAc - MurNAc -

Fig. 1. Fragment of the primary structure of cell wall peptidoglycan of Eubacterium aerofaciens JCM $10188^{\top}$.

from human faeces. In this study, seven strains which did not produce acid from sucrose or cellobiose were recognized and distinguished as group IV. These four groups were further divided into 16 sub-groups by their ability to ferment aesculin, salicin and amygdalin as shown in Table 3. Of the Eubacterium aerofaciens groups tested, group II was isolated at the highest incidence $(55.2 \%)$ and group I also occurred at high levels $(36 \cdot 6 \%)$.

\section{Chemotaxonomic characteristics}

The structure of the cell wall peptidoglycan of Eubacterium aerofaciens JCM $10188^{\mathrm{T}}$ was determined. The peptidoglycan contained, in addition to muramic acid and glucosamine, the amino acids glutamic acid,

Table 3. Grouping of the Eubacterium aerofaciens group by fermentation of five sugars

Data are based on the reactions of 178 Eubacterium aerofaciens-like strains and Eubacterium aerofaciens $\mathrm{JCM}^{10188^{\mathrm{T}}}$, JCM 7790 and JCM 7791.

\begin{tabular}{|c|c|c|c|c|c|c|c|c|c|c|c|c|c|c|c|c|}
\hline \multirow{2}{*}{$\begin{array}{l}\text { Group*... } \\
\text { Sub-group } \dagger \ldots\end{array}$} & \multicolumn{6}{|c|}{ I } & \multicolumn{7}{|c|}{ II } & III & \multicolumn{2}{|c|}{ IV } \\
\hline & $\mathbf{A}$ & B & C & D & $\mathbf{E}$ & $\mathbf{F}$ & $\mathbf{A}$ & B & C & D & $\mathbf{E}$ & $\mathbf{F}$ & G & $\mathbf{A}$ & $\mathbf{A}$ & B \\
\hline$n \ldots$ & 16 & 15 & 1 & 2 & 19 & 12 & 44 & 19 & 5 & 14 & 4 & 13 & 2 & 8 & 6 & 1 \\
\hline Sucrose & + & + & + & + & + & + & - & - & - & - & - & - & - & + & - & - \\
\hline Cellobiose & + & + & + & + & + & + & + & + & + & + & + & + & + & - & - & - \\
\hline Aesculin & - & - & - & + & + & + & - & + & - & - & + & + & + & - & - & + \\
\hline Salicin & - & + & + & - & + & + & - & - & + & - & - & + & + & - & - & - \\
\hline Amygdalin & - & - & + & + & - & + & - & - & - & + & + & - & + & - & - & - \\
\hline
\end{tabular}

* Groups are divided by fermentation pattern of sucrose and cellobiose.

$\dagger$ Groups are divided into 16 sub-groups by fermentation patterns of five sugars. 
Collinsella aerofaciens gen nov., comb. nov.

Table 4. DNA base composition and levels of DNA-DNA relatedness among Eubacterium aerofaciens strains

\begin{tabular}{|lcccc|}
\hline \multirow{2}{*}{ Strain } & \multirow{2}{*}{$\begin{array}{c}\text { G+C content } \\
(\mathbf{m o l} \%)\end{array}$} & \multicolumn{2}{c|}{ Percentage DNA-DNA reassociation with: } \\
\cline { 5 - 6 } & & JCM 10188 & JMC 7790 & JCM 7791 \\
\hline Eubacterium aerofaciens JCM 10188 & 61 & 100 & 84 & 75 \\
Eubacterium aerofaciens JCM 7790 & 60 & 82 & 100 & 74 \\
Eubacterium aerofaciens JCM 7791 & 61 & 75 & 73 & 100 \\
\hline
\end{tabular}

aspartic acid, ornithine and alanine at a molar ratio of $1: 1: 1: 2$, respectively. Both ornithine and aspartic acid occur in the L configuration; to determine the compostion of the isomers, the neutral amino acid fraction was reacted with a chiral reagent $[(+)-1-(9-$ fluorenyl)ethyl chloroformate] and analysed by HPLC. Until recently, only $D$-aspartic acid has been found in bacterial cell walls, but in this study of Eubacterium aerofaciens $\mathrm{L}$-aspartic acid was found. This indicated that the structural type was a previously unknown A4 $\beta$-type, (L-Ala)-D-Glu-L-Orn-L-Asp (Fig. 1). However, Willems et al. (1997) found that Holdemania filiformis, whose phenotypic and phylogenetic characters are similar to the genus Eubacterium, has Laspartic acid in its cell wall.

\section{DNA base composition and DNA-DNA relatedness}

The DNA base composition of Eubacterium aerofaciens JCM 10188 ${ }^{\mathrm{T}}$, JCM 7790 and JCM 7791 was $59 \cdot 8-61 \cdot 1 \mathrm{~mol} \% \mathrm{G}+\mathrm{C}$ by the HPLC nucleoside method (Table 4). The levels of DNA-DNA relatedness among three Eubacterium aerofaciens strains ranged from 73 to $84 \%$ (Table 4). The results show that these three strains are the same species.

\section{5 rDNA sequence analysis}

More than 1400 bases of the 16S rDNA sequences (positions 28-1492; Escherichia coli numbering system) of Eubacterium aerofaciens JCM $10188^{\mathrm{T}}$, JCM 7790 and JCM 7791 were determined, and these sequences have been deposited in the DDBJ database. Fig. 2 shows a phylogenetic tree based on calculated $K_{\text {nuc }}$ values created by using our sequences and those obtained from public databases. Fig. 3 shows a phylogenetic tree based on maximum-likelihood analysis. A database search demonstrated that Eubacterium aerofaciens belongs to the family Coriobacteriaceae, which contains the genera Coriobacterium and Atopobium (Hass \& König, 1988). A phylogenetic analysis showed that three strains of Eubacterium aerofaciens, JCM $10188^{\mathrm{T}}$, JCM 7790 and JCM 7791, had different characteristic fermentation patterns but that they created one cluster which was distant from other Eubacterium species and closest to Coriobacterium glomerans (Lewis \& Sutter, 1981). The sequence similarity values were: JCM $10188^{\mathrm{T}}$ vs JCM
$7790,96.6 \%$; JCM $10188^{\mathrm{T}}$ vs JCM 7791, 97.6\%; JCM 7790 vs JCM $7791,97 \cdot 8 \%$.

\section{DISCUSSION}

Of all members of the genus Eubacterium, one of the predominant micro-organisms in the intestinal microflora, Eubacterium aerofaciens is found at the highest levels and most frequently in the human intestine (Benno et al., 1986; Finegold \& Sutter, 1978; Moore \& Holdeman, 1974). Some characteristics and the phylogenetic position, however, are not clear. The definition of the genus Eubacterium was unclear and all species which were anaerobic, Gram-positive, non-sporing, rod-shaped bacteria which were not members of the genera Propionibacterium or Bifidobacterium were included in genus Eubacterium (Lewis \& Sutter, 1981; Moore \& Holdeman, 1986). Therefore, this genus contained many species with different characteristics and a broad range of $\mathrm{G}+\mathrm{C}$ contents, which caused considerable confusion (Nakazawa \& Hoshino, 1994).

Moore \& Holdeman (1974) reported that Eubacterium aerofaciens isolated from human intestine was mainly divided into three groups (I-III) by fermentation patterns of sucrose and cellobiose: group I uniformly produced acid from sucrose and cellobiose; group II uniformly produced acid from cellobiose but not from sucrose; and group III uniformly produced acid from sucrose but not from cellobiose. In the present study, 181 strains of the Eubacterium aerofaciens group were characterized using the fermentation patterns of sucrose and cellobiose and divided into four groups. Three groups were the same as in the previous study, but group IV which uniformly produced no acid from sucrose and cellobiose was different. Previously, none of the strains of the Eubacterium aerofaciens group tested produced acid from aesculin, salicin or amygdalin, but in the present study, some strains fermented these glycosides. They were divided into 16 sub-groups (I-A-F, II-A-G, III-A and IV-A and -B) according to fermentation patterns of aesculin, salicin and amygdalin (Table 3). These results showed that the Eubacterium aerofaciens group has very variable characters.

The genus Eubacterium was heterogeneous with respect to, for example, the $\mathrm{G}+\mathrm{C}$ content of DNA and the wide range of the phylogenetic positions 


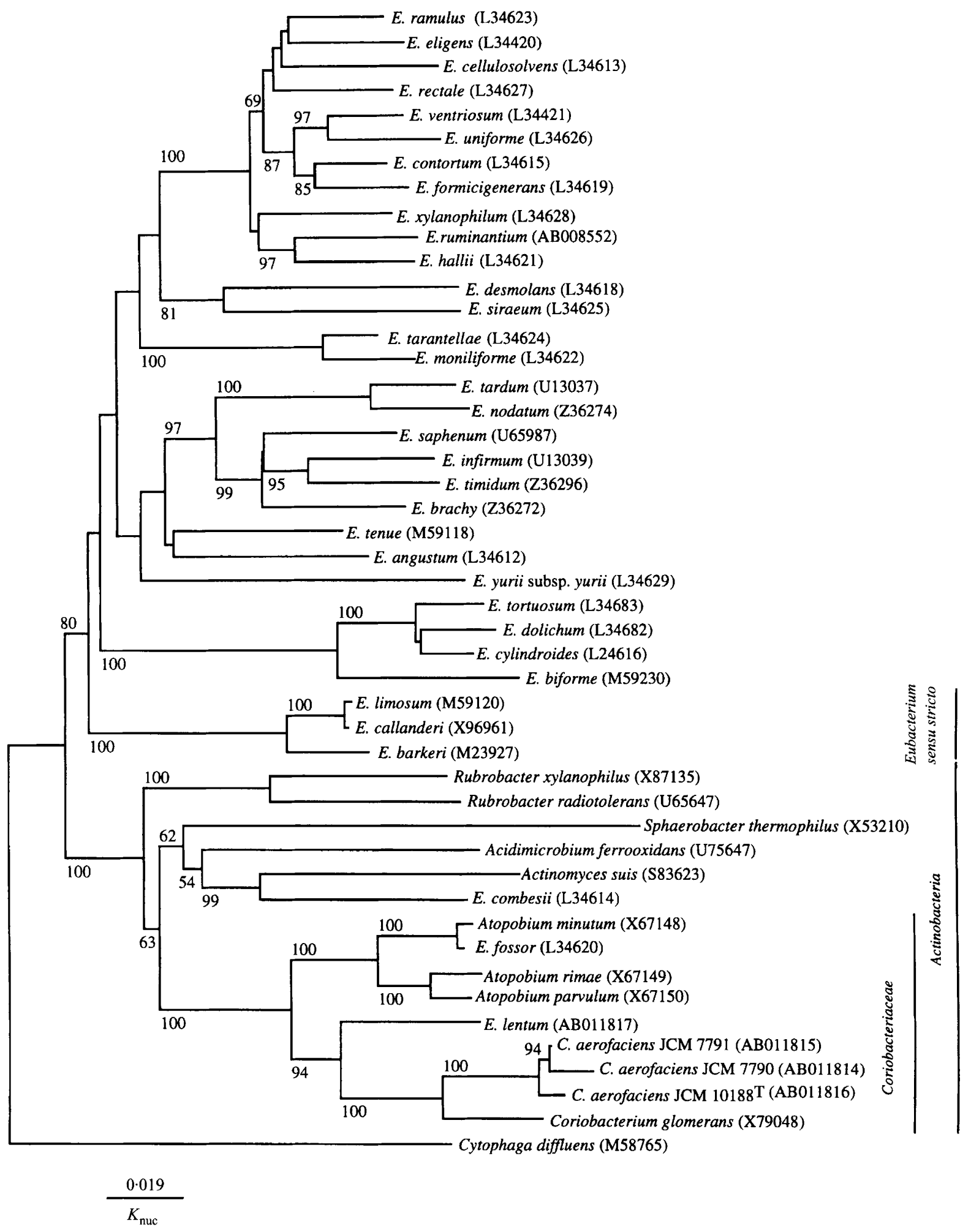

Fig. 2. Unrooted phylogenetic tree derived from $16 \mathrm{~S}$ rDNA sequences. The tree was created using the neighbour-joining method and $K_{\text {nuc }}$ values. The numbers on the tree indicate bootstrap values for the branch points. Only values above $50 \%$ significance are indicated. The sequence data for species other than Collinsella aerofaciens were obtained from the GenBank database. E., Eubacterium; C., Collinsella. 


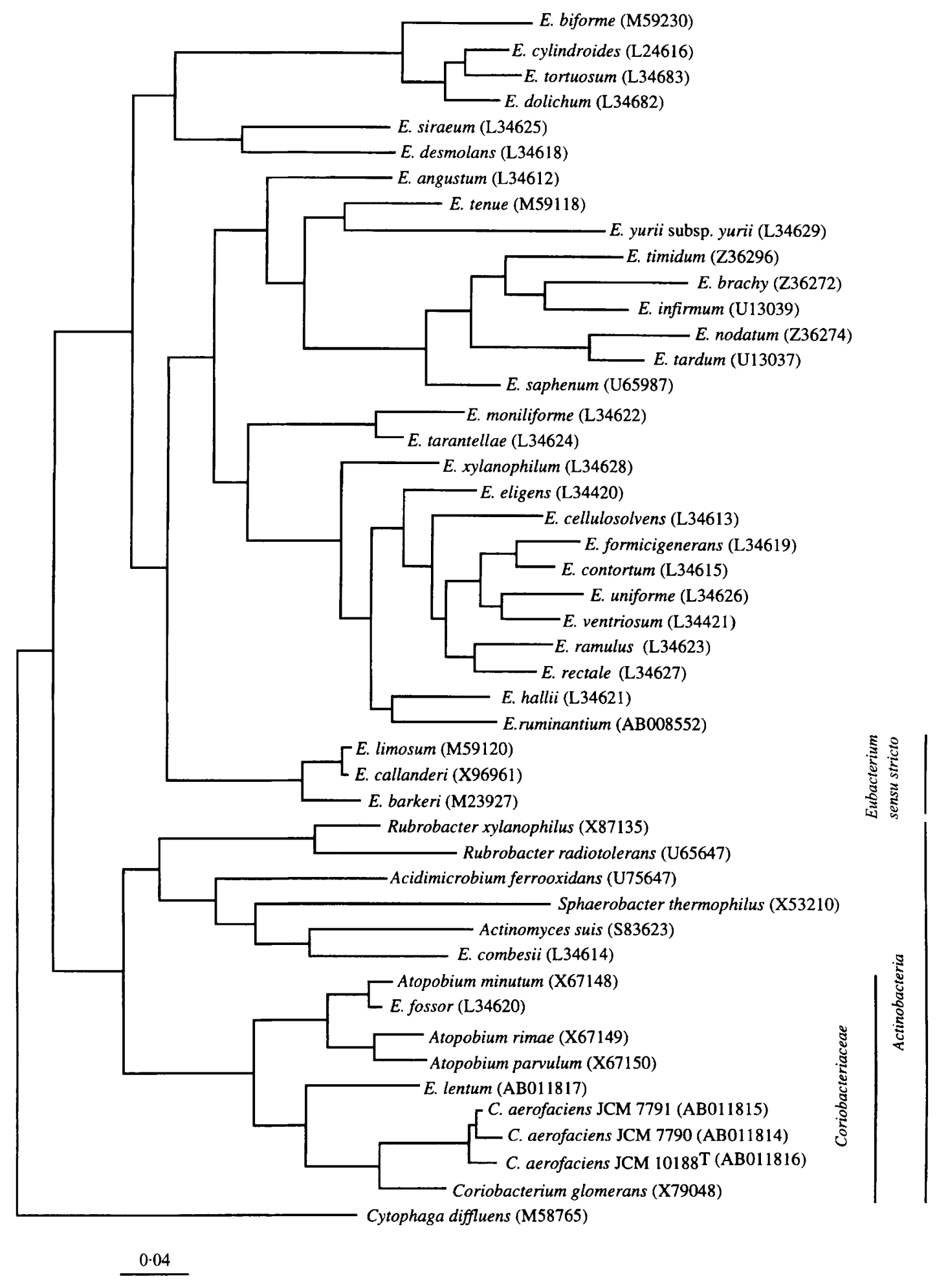

Fig. 3. Unrooted phylogenetic tree derived from $16 \mathrm{~S}$ rDNA sequence. The tree was created using maximum-likelihood analysis. The sequence data for species other than Collinsella aerofaciens were obtained from the GenBank database. E., Eubacterium; C., Collinsella.

(Nakazawa \& Hoshino, 1994). In the present study, the phylogenetic positions of the Eubacterium aerofaciens group were demonstrated using 16S rRNA sequences. A database search revealed that three strains of Eubacterium aerofaciens belonged to the actinomycetes line of descent. A new hierarchic classi- 
fication structure for the taxa between the taxonomic levels of genus and class is proposed for the actinomycete line of descent as defined by analysis of smallsubunit (16S) rRNA and genes encoding this molecule (rDNA). A new class, Actinobacteria, which contains the orders Acidimicrobiales, Rubrobacterales, Coriobacteriales, Sphaerobacterales, Actinomycetales and Bifidobacteriales, was proposed by Stackebrandt et al. (1997). The Eubacterium aerofaciens group belongs to class Coriobacteriales, family Coriobacteriaceae, and this family contains the genera Coriobacterium and Atopobium as a new classification.

To elucidate the topology of Eubacterium aerofaciens, two different phylogenetic analyses (neighbour-joining and maximum likelihood; Figs 2 and 3 ) were performed that included all species of the genus Eubacterium and all other taxa from the family Coriobacteriaceae - the genus Eubacterium is confused, because so many other genera, for example Clostridium, are close to it - thus genera outside the Coriobacteriaceae were omitted as the tree would have been too complex. Both our analyses showed that three strains of the Eubacterium aerofaciens group formed one cluster near Coriobacterium glomerans (Hass \& König, 1988). The genus Eubacterium was very heterogeneous, so a few different topologies occurred between the two analyses. However, the topology of family Coriobacteriaceae, which contains Eubacterium aerofaciens strains, was the same. The sequence similarity values were $96 \cdot 6-97 \cdot 8 \%$, which is not very high, and three strains of the Eubacterium aerofaciens group showed different sugar fermentations. Therefore, we checked the similarity of three strains based on DNA-DNA homology. The result showed that the three strains were the same species (Table 4).

The type species of genus Eubacterium is Eubacterium limosum. It is evident from recent studies that Eubacterium limosum, Eubacterium barkeri and Eubacterium callanderi (Mountfort et al., 1988) can form the nucleus of a redefined genus Eubacterium. On the basis of the characteristics of this group, a preliminary working definition of Eubacterium sensu stricto should be as follows: Gram-positive rod-shaped organisms that are non-motile and obligately anaerobic, may form endspores and are saccharolytic. The main end products from glucose fermentation are butyrate, acetate, lactate and $\mathrm{H}_{2}$. Formate or $\mathrm{CO}_{2}$ may also be produced by three species. The cell walls contain a type B peptidoglycan. The $\mathrm{G}+\mathrm{C}$ content of the DNA is $45-47 \mathrm{~mol} \%$ (Willems \& Collins, 1996).

Phylogenetic analysis of the Eubacterium aerofaciens group showed they varied widely from Eubacterium sensu stricto. The $\mathrm{G}+\mathrm{C}$ content of Eubacterium aerofaciens was much higher than that of Eubacterium sensu stricto and the cell wall contained A $4 \beta$-type peptidoglycan. On the other hand, Coriobacterium glomerans was anaerobic, Gram-positive and formed long chains of irregular pear-shaped cells with large spherical involutions. This species was isolated from the intestinal tract of red soldier bugs. This species also had a high DNA G $+C$ content of $60-61 \mathrm{~mol} \%$ and the peptidoglycan was Lys-Asp type. Coriobactrerium glomerans produced acetic acid, lactic acid, ethanol, $\mathrm{CO}_{2}$ and $\mathrm{H}_{2}$ from glucose as end products (Hass \& König, 1988).

From peptidoglycan amino acid analysis and the $16 \mathrm{~S}$ rRNA gene sequence composition, it is evident that this bacterium has a close phylogenetic relationship with Coriobactrerium glomerans. Although the association between these taxa is statistically significant, a sequence divergence of $>9 \%$ suggests that this relationship is that of two phylogenetically closely related, but nevertheless different, genera.

Based on 16S rRNA sequence analysis and the unique A4 $\beta$-type peptidoglycan, we propose that Eubacterium aerofaciens be reclassified as the first species of a new genus, Collinsella gen. nov., comb. nov.

\section{Description of Collinsella gen. nov.}

Collinsella (Col.lin.sel'la. M.L. fem. dim. ending -ella, M.L. fem. n. Collinsella named to honour Matthew D. Collins, a contemporary English microbiologist, for his outstanding contribution to microbial taxonomy and phylogeny).

Cells occur in chains of coccid cells. Gram-positive and obligately anaerobic. Spores and flagella are absent. Fermentation products of glucose are $\mathrm{H}_{2}$, ethanol, formate and lactate. Cell wall contains a A4 $\beta$-type peptidoglycan with an (L-Ala)-D-Glu-L-Orn-L-Asp peptide subunit whose interpeptide bridge consists only of L-Asp. DNA G + C content is $60-61 \mathrm{~mol} \%$. Type species is Collinsella aerofaciens. The genus Collinsella is a member of the Coriobacteriaceae and exhibits a close phylogenetic association with the genus Coriobacterium.

\section{Description of Collinsella aerofaciens [Eubacterium aerofaciens (Eggerth) Prévot 1938] comb. nov.}

Collinsella aerofaciens (ae.ro.fa'ci.ens. Gr. n. aer gas; L. v. facere to make, to produce; M.L. part. adj. aerofaciens gas-producing).

Cells are $0.3-0.7 \times 1 \cdot 2-4.3 \mu \mathrm{m}$ long and occur in chains of 6-120 coccid cells. Gram-positive and obligately anaerobic. Spores and flagella are absent. Colonies are white in the centre with clear surroundings and protuberant on EG agar. Can be cultivated for $2 \mathrm{~d}$ at $37^{\circ} \mathrm{C}$ on EG agar in an anaerobic jar with $100 \% \mathrm{CO}_{2}$. Cells produce acid from glucose, mannose, galactose, fructose, maltose and lactose but not from arabinose, xylose, melezitose, soluble starch, glycogen, mannitol, sorbitol, inositol or erythritol. Cell wall contains a A4 $\beta$-type peptidoglycan with an (L-Ala)-D-Glu-LOrn-L-Asp peptide subunit and interpeptide bridge consists only of L-Asp. DNA $\mathrm{G}+\mathrm{C}$ content is 61 mol\%. Type strain of Collinsella aerofaciens is strain 


\section{ACKNOWLEDGEMENTS}

We thank M. Chijimatsu for analysis of the cell wall and M. Matsue, Y. Kosako, T. Kudo and K. Suzuki for their excellent technical assistance. This work was supported by a grant from the Yakult Foundation for Bioscience Research.

\section{REFERENCES}

Andreesen, J. R. (1992). The genus Eubacterium. In The Prokaryotes, 2nd edn, pp. 1914-1924. Edited by A. Balows, H. G. Trüper, M. Dworkin, W. Harder \& K.-H. Schleifer. New York: Springer.

Benno, Y., Suzuki, K., Suzuki, K., Narisawa, K., Bruce, W. R. \& Mitsuoka, T. (1986). Comparison of the fecal microflora in rural Japanese and urban Canadians. Microbiol Immunol $\mathbf{3 0}$, 521-531.

Einarsson, S. \& Josefsson, B. (1987). Separation of amino acid enantiomers and chiral amines using precolumn derivatization with (+)-1-(9-fluorenyl)ethyl chloroformate and reversedphase liquid chromatography. Anal Chem 59, 1191-1195.

Ezaki, T., Hashimoto, Y. \& Yabuuchi, E. (1989). Fluorometric deoxyribonucleic acid-deoxyribonucleic acid hybridization in microdilution wells as an alternative to membrane filter hybridization in which radioisotopes are used to determine genetic relatedness among bacterial strains. Int J Syst Bacteriol 39, 224-229.

Felsenstein, J. (1985). Confidence limits on phylogenies: an approach using the bootstrap. Evolution 39, 783-791.

Finegold, S. M. \& Sutter, V. L. (1978). Fecal flora in different populations with special reference to diet. Am J Clin Nutr 27, 1456-1469.

Fujimura (1986). Determination of the nucleotide composition of a deoxyribonucleic acid by high-performance liquid chromatography of its enzymatic hydrolysate: a review. $J$ Microbiol Methods 4, 229-240.

Hass, H. \& König, H. (1988). Coriobacterium glomerans gen. nov., sp. nov. from the intestinal tract of the red soldier bug. Int J Syst Bacteriol 38, 382-384.

Holdeman, L. V., Cato, E. P. \& Moore, W. E. C. (1977). Anaerobic Laboratory Manual, 4th edn. Blacksburg, VA: Anaerobe Laboratory, Virginia Polytechnic Institute and State University. Kaneuchi, C., Watanabe, K., Terada, A., Benno, Y. \& Mitsuoka, T. (1976). Taxonomic study of Bacteroides clostridiiformis subsp. clostridiiformis (Burri and Ankersmit) Holdeman and Moore and related organisms: proposal of Clostridium clostridifforme (Burri and Ankersmit) comb. nov. and Clostridium symbiosum (Stevens) comb. nov. Int J Syst Bacteriol 26, 195-204.
Kawamoto, l., Oka, T. \& Nara, T. (1981). Cell wall composition of Micromonospora olivoasterospora, Micromonospora sagamiensis, and related organisms. J Bacteriol 146, 527-534.

Kimura, M. \& Ohta, T. (1972). On the stochastic model for estimation of mutation distance between homologous proteins. $J$ Mol Evol 2, 87-90.

Lewis, R. P. \& Sutter, V. L. (1981). The genus Eubacterium. In The Prokaryotes, pp. 1903-1911. Edited by M. P. Starr, H. Stolp, H. G. Trüper, A. Balows \& H. G. Schlegel. Berlin: Springer.

Moore, W. E. C. \& Holdeman, L. V. (1974). Human fecal flora: the normal flora of 20 Japanese-Hawaiians. Appl Microbiol 27, 961-979.

Moore, W. E. C. \& Holdeman-Moore, L. V. (1986). Genus Eubacterium Prevot 1938. In Bergey's Manual of Systematic Bacteriology, vol. 2, pp. 1353-1373. Edited by P. H. A. Sneath, N. S. Mair, M. E. Sharpe \& J. G. Holt. Baltimore: Williams \& Wilkins.

Mountfort, D. O., Grant, W. D., Clarke, R. \& Asher, R. A. (1988). Eubacterium callanderi sp. nov. that demethoxylates $O$ methoxylated aromatic acids to volatile fatty acids. Int $J$ Syst Bacteriol 38, 254-258.

Nakazawa, F. \& Hoshino, E. (1994). Genetic relationships among Eubacterium species. Int J Syst Bacteriol 44, 787-790.

Saito, H. \& Miura, K. (1963). Preparation of transforming deoxyribonucleic acid by phenol treatment. Biophys Acta 72,

Saitou, N. \& Nei, M. (1987). The neighbor-joining method: a new method for reconstructing phylogenetic trees. Mol Biol Evol 4, 406-425.

Stackebrandt, E., Rainey, F. A. \& Ward-Rainey, N. L. (1997). Proposal for a new hierarchic classification system, Actinobacteria classis nov. Int J Syst Bacteriol 47, 479-491.

Tamaoka, J. \& Komagata, K. (1984). Determination of DNA base composition by reversed-phase high-performance liquid chromatography. FEMS Microbiol Lett 25, 125-128.

Thompson, J. D., Higgins, D. G. \& Gibson, T. J. (1994). CLUSTAL $\mathrm{W}$ : improving the sensitivity of progressive multiple sequence alignment through sequence weighting, position specific gap penalties and weight matrix choice. Nucleic Acids Res 22, 4673-4680.

Willems, A. \& Collins, M. D. (1996). Phylogenetic relationships of the genera Acetobacterium and Eubacterium sensu stricto and reclassification of Eubacterium alactolyticum as Pseudoramibacter alactolyticus gen. nov., comb. nov. Int $J$ Syst Bacteriol 46, 1083-1087.

Willems, A., Moore, W. E. C., Weiss, N. \& Collins, M. D. (1997). Phenotypic and phylogenetic characterization of some Eubacterium-like isolates containing a novel type B wall murein from human feces: description of Holdemania filiformis gen. nov., sp. nov. Int J Syst Bacteriol 47, 1201-1204. 